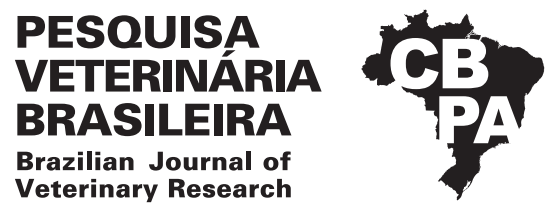

Pesq. Vet. Bras. 38(12):2224-2232, dezembro 2018 DOI: 10.1590/1678-5150-PVB-5524

Original Article

ISSN 0100-736X (Print)

ISSN 1678-5150 (Online)

\title{
$\beta$ Lapachone blocks the cell cycle and induces apoptosis in canine osteosarcoma cells ${ }^{1}$
}

\author{
Vanessa S. Cruz ${ }^{2 *}$, Fernanda A. Rodrigues², Karla M.S. Braga², Patrícia A. Machado², \\ Cesario Bianchi Filho ${ }^{3}$, Yandra C.L. Prado ${ }^{4}$ and Eugênio G. Araújo ${ }^{2}$
}

\begin{abstract}
Cruz V.S., Rodrigues F.A., Braga K.M.S., Machado P.A., Bianchi Filho C., Prado Y.C.L. \& Araújo E.G. 2018. $\beta$ Lapachone blocks the cell cycle and induces apoptosis in canine osteosarcoma cells. Pesquisa Veterinária Brasileira 38(12):2224-2232. Post-Graduate Program in Animal Science, Laboratório Multiusuário de Cultivo Celular, Universidade Federal de Goiás, Campus Universitário Samambaia, Avenida Esperança s/n, Goiânia, GO 74690-900, Brazil. E-mail: vanessascpimenta@yahoo.com.br

Osteosarcoma is a malignant tumor of primitive bone cells with a high incidence in dogs and humans. The need for more effective drugs with less adverse consequences has pushed the development of chemotherapeutic agents from plants and other natural sources. The aim of this study was to verify the cytotoxic effects of $\beta$-lapachone, a compound present in the sawdust of Tabebuia sp. (popularly known as ipê) wood, on canine osteosarcoma cells subcultured and treated in different concentrations $(0.1 \mu \mathrm{m}, 0.3 \mu \mathrm{m}$ e $1.0 \mu \mathrm{m})$ and exposure times $(24 \mathrm{~h}, 48 \mathrm{~h}$ e $72 \mathrm{~h}$ ). Results were obtained through Trypan blue dye exclusion, tetrazolium reducing method, cell survival assay, Annexin V-FITC and Propidium Iodine labeling, JC-1 dye labeling and cell cycle kinetics e analysis. The group treated with $0.3 \mu \mathrm{m} \beta$-lapachone presented higher decrease in cell viability $(80.27 \%, 24 \mathrm{~h}, 47.41 \%, 48 \mathrm{~h}$ and $35.19 \%, 72 \mathrm{~h})$ and greater progression of cytotoxicity $(19.73 \%, 24 \mathrm{~h}, 52.59 \%, 48 \mathrm{~h}$ and $64.81 \%, 72 \mathrm{~h})$. The lower $\mathrm{IC}_{50}(0.180 \mu \mathrm{m})$ was verified in the group treated for 72 hours. Cell growth after treatment decreased as concentration and time of exposure increased, with $0.50 \%$ survival fraction at the concentration of $1.0 \mu \mathrm{m}$. Initial apoptosis was the most frequent type of cell death in all groups, reaching bottom in the 24 -hour group treated with $0.1 \mu \mathrm{m}(4.26 \%)$ and peaking in the 72-hour group treated with $1.0 \mu \mathrm{m}(85.89 \%)$. Mitochondrial depolarization demonstrated a dose-dependent phenomenon, indicating the intrinsic apoptosis. Cell growth inhibition by blocking cell cycle in the G0/G1 phase related to the exposure the time. $\beta$-lapachone is cytotoxic for canine osteosarcoma cells, induces apoptosis and promotes cell cycle arrest in $\mathrm{G} 0 / \mathrm{G1}$ phase.
\end{abstract}

INDEX TERMS: $\beta$ Lapachone, cell cycle, induces apoptosis, canine osteosarcoma, lapachol, lineage D-17, ipê, naphthoquinone, Tabebuia sp., pathology.

RESUMO.- [ $\beta$ Lapachona bloqueia o ciclo celular e induz apoptose em células de osteossarcoma canino.] 0 osteossarcoma é o tumor maligno das células ósseas primitivas,

\footnotetext{
${ }^{1}$ Received on June 7, 2018.

Accepted for publication on June 19, 2018.

Project with support from CNPq.

${ }^{2}$ Post-Graduate Program in Animal Science, Laboratório Multiusuário de Cultivo Celular, Universidade Federal de Goiás (UFG), Campus Universitário Samambaia, Avenida Esperança s/n, Goiânia, GO 74690-900, Brazil. *Corresponding author: vanessascpimenta@yahoo.com.br

${ }^{3}$ Universidade de Mogi Das Cruzes, Avenida Dr. Cândido Xavier de Almeida Souza 200, Centro Cívico, Mogi das Cruzes, SP 08780-911, Brazil.

${ }^{4}$ Centro Universitário Nossa Senhora do Patrocínio (CEUNSP), Rua Adão Hoffmann 128, Vila Industrial, Campinas, SP 13035-010, Brazil.
}

com alta incidência em cães e humanos. A necessidade de medicamentos mais efetivos, com menor consequência adversa, tem gerado esforços para o desenvolvimento de agentes quimioterápicos compostos por plantas e outras fontes naturais. $\mathrm{O}$ objetivo deste estudo foi verificar os efeitos citotóxicos da $\beta$ lapachona, um composto presente na serragem da madeira do ipê, sobre células de osteossarcoma canino subcultivadas e submetidas ao tratamento, de acordo com as diferentes concentrações $(0,1 \mu \mathrm{m} ; 0,3 \mu \mathrm{m}$ e $1,0 \mu \mathrm{m})$ e tempo de exposição $(24 \mathrm{~h}, 48 \mathrm{~h}$ e $72 \mathrm{~h})$. Os resultados foram obtidos por meio dos métodos de exclusão do corante azul de Tripan e de redução do tetrazólio, além dos ensaios de sobrevivência celular, de dupla marcação com Anexina V-FITC 
e Iodeto de Propídio, de marcação com o corante JC-1 e pela análise da cinética do ciclo celular. 0 grupo tratado com $0,3 \mu \mathrm{m}$ de $\beta$ lapachona apresentou melhor regressão da viabilidade celular $(80,27 \%, 24 \mathrm{~h} ; 47,41 \%$, 48h e $35,19 \%, 72 \mathrm{~h})$ e maior progressão da citotoxicidade $(19,73 \%, 24 \mathrm{~h} ; 52,59 \%$, $48 \mathrm{~h}$ e $64,81 \%, 72 \mathrm{~h}) .0$ menor $\mathrm{IC}_{50}(0,180 \mu \mathrm{m})$ ocorreu no grupo tratado por 72 horas. 0 crescimento celular após o tratamento foi menor, de acordo com o aumento da concentração e tempo de exposição, apresentando 0,50\% de fração de sobrevivência na concentração de 1,0 $\mu \mathrm{m}$. A apoptose inicial foi o tipo de morte celular mais frequente em todos os grupos, menor no grupo de 24 horas tratado com $0,1 \mu \mathrm{m}(4,26 \%)$ e maior no grupo de 72 horas tratado com 1,0 $\mu$ m (85,89\%). A despolarização mitocondrial ocorreu de maneira dose dependente, indicando a ocorrência de apoptose intrínseca. A $\beta$ lapachona possui efeitos citotóxicos em células de osteossarcoma canino, induz apoptose e promove o bloqueio do ciclo celular na fase G0/G1.

TERMOS DE INDEXAÇÃO: $\beta$ Lapachona, ciclo celular, apoptose em células, osteossarcoma canino, lapachol, linhagem D-17, ipê, naftoquinona, Tabebuia sp., patologia.

\section{INTRODUCTION}

Osteosarcoma (OS) corresponds to $6 \%$ of incidental neoplasms in dogs, $80 \%$ of bone tumors and its prognosis is usually reserved (Nelson \& Couto 2015, Neuwald et al. 2006, Karnik et al. 2012, Krajarng et al. 2012). In humans it represents $60 \%$ of all neoplasms that affect in the first two decades of life (Hofstaetter et al. 2013, Ouyang et al. 2013).

Therapy to induce remission of OS in dogs and humans includes the use of various substances such as cisplatin, carboplatin, ifosfamide, doxorubicin, and methotrexate (Osborne \& Khanna 2012, Cinegaglia et al. 2013, Batschinski et al. 2014). Adverse effects reflect on cardiotoxicity, nephrotoxicity, ototoxicity and hepatotoxicity (Gallagher et al. 2012, Zhang et al. 2013). A significant number of human OS patients still respond poorly to intensive chemotherapy and are at risk of local recurrence or distant metastases (Ouyang et al. 2013).

Brazil has a flora rich in biological diversity and, in particular, the Brazilian cerrado biome contains tropical medicinal plants, with potential for the development of chemotherapeutic agents, with analgesic, tranquilizing, diuretic, laxative, antibiotic and antineoplastic properties (Souza \& Felfili 2006). There are approximately 46 types of wood in Brazil under the designation of ipê (Silva et al. 2003). In the plants of the bignoniaceous family, Tabebuia avellanedae, T. serratifolia, T. heptaphyla, Zeyhera digitalis and Z. tuberculosa, are found naphthoquinones, in addition to other compounds such as flavonoids, lignans, monoterpenes, triterpenes, cinnamic acids, benzoic (Fonseca et al. 2003, Silva et al. 2003, Hussain et al. 2007, Silva 2009).

The derivatives of naphthoquinones present cytotoxic and genotoxic potential by the interaction with nucleophilic biomolecules, such as protein and non-protein thiols (glutathione), and by interference in the action of cellular enzymes involved in the process of cell proliferation (Klaus et al. 2010). Lapachol (LP) is a naphthoquinone with several biological properties and without serious side effects (Thomson 1997, Martin-Navarro et al. 2010). At the end of the 19th century, the conversion of lapachol into alpha-Lapachone and beta-Lapachone ( $\beta$ LP) by acid cyclization was described (Silva et al. 2007). $\beta$ LP (3.4-dihydro-2, 2-dimethyl-2H-naphthol [1.2-b] pyran-5.6-dione), a substance used in this study, has antibacterial, antifungal and antiretroviral activity (Pardee et al. 2002, Aires et al. 2014). It is known that this compound has good results in prolonging the survival of leukemia models, blocking the multiplication of human immunodeficiency virus (HIV-1), as adjuvant therapy in proliferative retinopathy, as an anti-psoriatic agent, and has schistosomicidal activity (Pardee et al. 2002, Aires et al. 2014). The fact that it is inhibiting DNA topoisomerase $\mathrm{I}$, an enzyme that plays an important role in the processes of replication and packaging of DNA, triggered studies on the antineoplastic action of $\beta \mathrm{LP}$ in tumors implants in in vivo mice, such as cancers of prostate, ovary and breast, as well as in human cells of in vitro cultivation, such as prostate and lung (Pardee et al. 2002, Kung et al. 2014).

This study aims to verify the cytotoxic effects of $\beta \mathrm{LP}$, its action in the progression of the cell cycle and the process of cell death in the lineage of canine osteosarcoma, since this substance has antitumor activity in several types of neoplasms. The confirmation of its efficacy on the OS can allow the development of a more efficient therapeutic strategy and with less adverse effect for the patient.

\section{MATERIALS AND METHODS}

Osteogenic metastatic canine osteosarcoma (COS) cells (D-17, BCRJ 0276, Lot 000573, Passage 239) were acquired from the Rio de Janeiro Cell Bank (UFRJ, Rio de Janeiro, Brazil) originating from the ATCC (American Type Culture Collection, Manassas/VA, USA). The cells were kept in a humidified incubator at $37^{\circ} \mathrm{C}$ with an atmosphere of $5 \%$ of $\mathrm{CO}_{2}$. They were cultivated in Dulbecco modified eagle medium (DMEM) plus $10 \%$ of bovine fetal serum, penicillin and streptomycin $(10,000$ U.I./ML $-10 \mathrm{mg} / \mathrm{ml})$, amphotericin B and L glutamine (all the reagents from Cultilab, Campinas, Brazil), according to the adaptation of Yu et al. 2014.

The cells were sown in culture plates and submitted or not to treatments with $\beta$ LP, acquired from Santa Cruz Biotechnology (Dallas, Texas, USA), according to the previously prepared concentrations, in the dosages of $0.1 \mu \mathrm{m}, 0.3 \mu \mathrm{m}, 1.0 \mu \mathrm{m}$, in three different periods for each concentration, for $24 \mathrm{~h}\left(\mathrm{G}_{24}\right), 48 \mathrm{~h}\left(\mathrm{G}_{48}\right)$ and $72 \mathrm{~h}\left(\mathrm{G}_{72}\right)$. The negative control group (CG) received treatment with DMSO free of $\beta \mathrm{LP}$ in the same periods. All assays were performed with three independent experiments in triplicate.

For the Cell Viability Assay (Mosmann 1983, Peres \& Curi 2005), 96-well plates with cells at the concentration of $1 \times 10^{4}$ were used, and after the treatment period, the mean of each well was discarded, and the cells suspended in trypsin (Cultilab, Campinas, São Paulo, Brazil), centrifuged and resuspended. Then the cells were stained with Trypan blue dye (Trypan Blue - Sigma - Aldrich, St Louis, USA). The evaluation of cell viability was performed using the Luna Automated cell counter reader. The cytotoxicity was determined, and the values calculated for each group by the F test, then were compared to the $\mathrm{F}$ tabulated in $5 \%$ (2.2).

To calculate the concentration value that inhibits $50 \%$ of the cell viability (inhibitory concentration - $\mathrm{IC}_{50}$ ), 96 wells with cells at the concentration of $1 \times 10^{4}$ were used (Yu et al. 2014) At the end of the treatment period, $10 \mu \mathrm{l}$ of tetrazolium (MTT (3-(4.5-Dimethyl-2-thiazolil) -2.5-diphnyl-2H-tetrazolium) were added to each well. After incubation period of 3 hours, $50 \mu \mathrm{l}$ of Sodium Dodecyl Sulfate (SDS - Vivantis Biochemical) was added to $10 \%$ diluted in $\mathrm{HCL} / 0.01 \mathrm{~N}$ per well. The plates remained incubated for 24 hours at room temperature. The optical density was quantified 
in a spectrophotometer. The $\mathrm{IC}_{50}$ was determined using the statistical program GraphPad Prism 6 (GraphPad Software, San Diego/CA, USA).

The cell survival assay (Cao et al. 2014, Park et al. 2014) was made in six-well plates with cells at the concentration of $1 \times 10^{6}$. The mean of each well was discarded after the treatment period and the cells were suspended in trypsin, centrifuged, resuspended and cultivated in six-well plates. The mean was discarded after 10 days, the wells were washed with PBS, the cells fixed with solution containing methyl alcohol (Impex/Labinpex) and acetic acid (Synth/Labsynth, Diadema, Sao Paulo, Brazil) and, finally, stained with $500 \mu$ l of Giemsa (Giemsa stain, Sigma-Aldrich, St Louis, USA). Each well was divided into nine fields for quantification of the cells in inverted microscope; the average of the fields per well and the calculation of the survival fractions was performed. The data were analyzed by the F test and compared to the $\mathrm{F}$ tabulated in $5 \%$ (2.2).

For the double marking assay (Park et al. 2014, Yu et al. 2014), the cells were cultivated and treated in 12 -well plates at a concentration of $5 \times 10^{5}$. Then, the mean of each well was discarded, the cells were suspended and centrifuged. $400 \mu \mathrm{l}$ of connection buffer and $5 \mu \mathrm{l}$ of V-FITC Annexin and $1 \mu \mathrm{l}$ of Propidium Iodine were added (Annexin V Apoptosis Detection Kit I-BD Biosciences, San Diego, USA), and the material was analyzed by the flow cytometer (Facscalibur, BD Biosciences). The cells marked only by Annexin $\mathrm{V}$ were classified as initial apoptosis. The cells marked by Annexin V and Propidium Iodine were classified as late apoptosis. The cells marked only by the Propidium Iodine were classified as necrosis. Cells that did not present any markings were considered viable. The data were transferred to the GraphPad Prism statistical graphics program. Data analysis, according to the classification of the column factor, estimated the individual values of viable cells, initial apoptosis, late apoptosis and necrosis. Data analysis, according to the line factor classification, compared the values found in each concentration.

In the Mitochondrial Membrane Potential Assay (Yu et al. 2014), the cells were cultivated in 12-well plates with the concentration of $5 \times 10^{5}$. At the end of the treatment period, the mean of each well was discarded, the cells suspended, centrifuged, resuspended and incubated with the JC- 1 dye for 15 minutes at $37^{\circ} \mathrm{C}$. At the end of this period, they were washed with PBS and resuspended in a test buffer. The results were obtained through the flow cytometer and analyzed by GraphPad Prism statistical graphics program. Data analysis, according to the classification of the column factor, estimated the individual values of viable cells and apoptosis. Data analysis, according to the line factor classification, compared the values found in each concentration.

The cell cycle analysis was performed using 12-well plates with cells at the concentration of $5 \times 10^{5}$. After the treatment period, the mean of each well was discarded, the cells were suspended, centrifuged and incubated for 24 hours at $-20^{\circ} \mathrm{C}$ in ethyl alcohol at $70 \%$ stored previously at $4^{\circ} \mathrm{C}$. After this period, the material was incubated in a solution containing ribonuclease a (Ribonuclease A from Bovine Pancreas, Sigma Aldrich, St Louis, USA) 0.05\%, in a water bath at $37^{\circ} \mathrm{C}$ for 30 minutes. There was a new centrifugation, the ribonuclease was discarded, the cells were resuspended in PBS and the Propidium Iodine was added. The percentage of cells in G1, S, G2 and sub-G1 was analyzed in flow cytometer and the results were analyzed by GraphPad Prism statistical graphics program. Data analysis, according to the classification of the column factor, estimated the individual values of the cells found in each phase of the cell cycle. Data analysis, according to the line factor classification, compared the values found in each concentration.

\section{RESULTS AND DISCUSSION}

Cytotoxicity (CT) was measured using the cell viability assay by the method of exclusion of the Trypan blue dye. The $\mathrm{G}_{72}$ with $0.3 \mu \mathrm{m}$ treatment showed lower cellular viability $(35.19 \%)$. The $\mathrm{G}_{24}$ with $0.3 \mu \mathrm{m}$ treatment showed higher cellular viability $(80.27 \%)$. All groups presented CT, demonstrating that $\beta \mathrm{LP}$ is cytotoxic to OSC cells. At the dosage of $0.1 \mu \mathrm{m}$ there was no statistical difference between the times of exposure to the $\beta$ LP. The statistical difference occurred in the groups that were treated with $0.3 \mu \mathrm{m}$, concentration that presented the best regression of cell viability $(\mathrm{CV})$ and better progression of cytotoxicity (CT), by time of exposure. Cytotoxicity rose from $19.73 \%$ in $\mathrm{G}_{24}$ to $52.59 \%$ in $\mathrm{G}_{48}$ and reached $64.81 \%$ in $\mathrm{G}_{72}$. Corroborating the results of Aires et al. (2014), according to which the $\beta$ LP has cytotoxic activity in several cells of human tumors.

Other to what found in the present study, the viability of OSC cells presented dose-dependent decrease when treated with $\alpha$ mangostin, a substance extracted from mangosteen, a tropical fruit found in Southeast Asia (Krajarng et al. 2012). Similarly, Cinegaglia et al. (2013) described that the human osteosarcoma cells (HOS) were sensitive to the dose-dependent cytotoxic effect at concentrations between $50 \mu \mathrm{g}$ to $100 \mu \mathrm{g}$ of propolis, a product collected from exudates of plants mixed with wax and saliva enzymes of bees. Also, the methoxsalen, a natural compound found in seeds of several plants, was cytotoxic to osteosarcoma cells MG63, in the dosages between $300 \mu \mathrm{m}$ and $500 \mu \mathrm{m}$ (Lu et al. 2017). On the other hand, carboplatin did not present cytotoxic activity in OSC cells in the assays performed by Stein et al. (2011) and in HOS cells in the study by Robson et al. (2007).

The concentration $0.3 \mu \mathrm{m}$ is expressively lower than the lethal concentrations used in the first studies on the $\beta$ LP for different cells in cultivation, ranging between $1.0 \mu \mathrm{m}$ and $30.0 \mu \mathrm{m}$ (Docampo et al. 1979). It also differed from the report by Pardee et al. (2002), in which the $\beta \mathrm{LP}$, in a dose of $2.0 \mu \mathrm{m}$ to $10 \mu \mathrm{m}$, presented lethality against several tumor cells in cultivation and delayed the growth of prostate, breast and ovarian tumor cells in vivo.

The results of the efficacy measure of $\beta \mathrm{LP}$ indicated that the concentration required for $50 \%$ in vitro inhibition in $G_{24}$ was $0.959 \mu \mathrm{m}$, in $\mathrm{G}_{48}$ was $1.657 \mu \mathrm{m}$, and in $\mathrm{G}_{72}$ was $0.180 \mu \mathrm{m}$. The variation in the values of $\mathrm{IC}_{50}$ can be attributed to the sensitivity to the effects of the substance in the different exposure times and to the metabolism of the drug. The low concentrations found by $\mathrm{IC}_{50}$ in the present study may be suggestive to lower adverse effects to the patient than that of HOS cells treated with concentrations between $50 \mu \mathrm{m}$ and $100 \mu \mathrm{m}$ of baicalein, a substance used in popular treatments in China (Zhang et al. 2013).

The mean number of OSC cells, verified after the incubation period of the cell survival assay, revealed a dose-dependent decrease in groups $G_{24}$ ( 5 cells $/ 0.1 \mu \mathrm{m} ; 3$ cells $/ 0.3 \mu \mathrm{m}$, and 0.55 cell $/ 1 \mu \mathrm{m}), \mathrm{G}_{48}$ (1.33 cells $/ 0.1 \mu \mathrm{m} ; 0.88$ cells $/ 0.3 \mu \mathrm{m}$, and 0.33 cell $/ 1.0 \mu \mathrm{m})$ and $\mathrm{G}_{72}(1.22$ cells $/ 0.1 \mu \mathrm{m} ; 0.22$ cell $/ 0.3 \mu \mathrm{m}$, and $0.11 \mathrm{cell} / 1.0 \mu \mathrm{m})$. The higher the concentration and the exposure time, the lower the cell survival. It was possible to perceive that in the CG ( 56 cells/ 24 hours; 24.66 cells/ 48 hours and 41.22 cells $/ 72$ hours) there was cell growth compatible with the absence of treatment by $\beta$ LP. The decrease in the number of cells with the period of treatment in this group is 
probably due to the restriction in relation to exposure time and space for growth.

The calculation of the survival fractions was made to compare the number of cells found in the groups treated with the number of cells observed in the CG. It was observed that the cell growth after treatment was lower $(0.50 \%)$ in the $\mathrm{G}_{72}$ with the concentration of $1.0 \mu \mathrm{m}$ and higher $(13.93 \%)$ in the $\mathrm{G}_{24}$ with the concentration of $0.3 \mu \mathrm{m}$. The data suggest that, after treatment with $\beta$ LP, there was a little significant resumption of cell growth. The cell survival assay is important to analyze the proliferative capacity of cells after exposure to a certain antiproliferative agent (Plumb 2004).

The results obtained in relation to cell proliferation suggest possible effect of BLP in combating recurrences, as already observed in models of xenograft of breast cancer in mice treated with $\beta$ Lapachone. The animals remained healthy for 200 days after the end of treatment and were considered cured (Cao et al. 2014). On the other hand, it is important to analyze this effect for longer periods in future research, because the use of cytotoxic agents and signal transduction inhibitors can promote the elimination of cancer cells in the short term, but the recurrence of residual cells may occur with drug resistance (Flick et al. 2013). In this sense, a problem reported in the case of HOS is the possibility of local recurrence with the use of conventional treatments, such as analgesics, radiation therapy, surgery and chemotherapy (Krajarng et al. 2012).

The values calculated for each group using the $\mathrm{F}$ test were compared to $\mathrm{F}$ tabulated $5 \%(2.2)=19$. It was concluded that there was no statistical difference for cell growth between the different concentrations and times of exposure to $\beta L P$. This may indicate that, even with low concentration and short interval of exposure time, cell growth after treatment was minimal. Similarly, Kung et al. (2014) reported a small percentage of survival of human lung cancer cells, using concentrations between $1.0 \mu \mathrm{m}$ and $5.0 \mu \mathrm{m}$ of $\beta \mathrm{LP}$.

By double marking test with Annexin V and Propidium Iodine (Table 1) was observed that cells in initial apoptosis were marked only by Annexin V, the cells in late apoptosis were marked by Annexin V and Propidium Iodine, and the cells in necrosis were marked only by the Propidium Iodine (Fig.1). Viable cells did not present any markings. Data on the mechanism of death of the cell, promoted by $\beta$ Lapachone in canine osteosarcoma cells, are presented in Tablet 1.

There was a prevalence of initial apoptosis in all concentrations of $\mathrm{G}_{48}$ and $\mathrm{G}_{72}$. Late apoptosis was higher in the $1.0 \mu \mathrm{m}$ concentration of the $\mathrm{G}_{24}$. The concentration of $1.0 \mu \mathrm{m}$ presented a higher rate of apoptosis in the three exposure times. There was no statistically significant difference between repetitions and triplicate values in each concentration $(\mathrm{P}=1.000)$. Initial apoptosis was the most frequent type of cell death in all groups. However, there was a statistically significant difference between the results found in the concentrations used in each treatment group $(\mathrm{p}<0.0001)$. Initial apoptosis occurred in a dose-dependent manner. It was lower in the group of 48 hours treated with $0.1 \mu \mathrm{m}$ of $\beta$ Lapachone (5.22\%) and higher in the group of 72 hours treated with $1.0 \mu \mathrm{m}$ of $\beta$ Lapachone $(85.89 \%)$

These results indicate that the reduction of the viability of the canine osteosarcoma cells after treatment with the $\beta$ Lapachone is related to apoptosis. The same mechanism of cell death by $\beta$ Lapachone was reported by Pardee et al. (2002) in glioma cells and human colon cancer. Kung et al. (2014) observed that apoptosis was induced in lung cancer cells by this substance by decreasing the activation of the proliferation factors. However, there was disagreement with the study done by Park et al. (2014), where the induction of programmed necrosis, by $\beta$ lapachone, was observed in cells of human hepatocellular carcinoma. For Flick et al. (2013), death of the cell by necrosis may occur with the use of $\beta$-lapachone treatment, since this compound potentializes the immune system, by means of factors associated with inflammation. Other compounds used for treatment of human osteosarcoma, such as loperamide (Regan et al. 2014), survivin (Shoeneman et al., 2012), baicalein (Zhang et al. 2013), MiR-335 (Liu et al. 2016) and mangosteen (Krajarng et al. 2012), also induce apoptosis. Doxorubicin induces autophagy in human osteosarcoma cells (Chang et al. 2014).

Table 1. Mean of the data provided by the flow cytometer on the mechanism of cell death promoted by $\beta$ Lapachone in canine osteosarcoma cells

\begin{tabular}{|c|c|c|c|c|c|}
\hline $\begin{array}{l}\text { Treatment time } \\
\text { (hours) }\end{array}$ & Concentration & $\begin{array}{l}\text { Viable } \\
\text { cells }\end{array}$ & $\begin{array}{c}\text { Initial } \\
\text { apoptosis }\end{array}$ & $\begin{array}{c}\text { Late } \\
\text { apoptosis }\end{array}$ & Necrosis \\
\hline \multirow{2}{*}{24} & $0.1 \mu \mathrm{M}$ & 75.35 & 19.02 & 2.02 & 3.42 \\
\hline & $1.0 \mu \mathrm{M}$ & 3.27 & 29.49 & 49.97 & 14.54 \\
\hline \multirow[t]{2}{*}{48} & $\mathrm{NC}^{*}$ & 83.66 & 6.36 & 3.73 & 6.58 \\
\hline & $1.0 \mu \mathrm{M}$ & 6.58 & 80.06 & 12.58 & 0.77 \\
\hline \multirow[t]{4}{*}{72} & $\mathrm{NC}^{*}$ & 75.33 & 14.57 & 4.56 & 5.55 \\
\hline & $0.1 \mu \mathrm{M}$ & 86.44 & 5.12 & 4.76 & 3.68 \\
\hline & $0.3 \mu \mathrm{M}$ & 27.96 & 54.81 & 9.99 & 7.23 \\
\hline & $1.0 \mu \mathrm{M}$ & 5.08 & 85.89 & 8.93 & 0.09 \\
\hline
\end{tabular}

Presentation of data on the mechanism of death of the cell promoted by $\beta$ Lapachone in cells of canine osteosarcoma. ${ }^{*} \mathrm{NC}=\mathrm{Negative}$ control. 

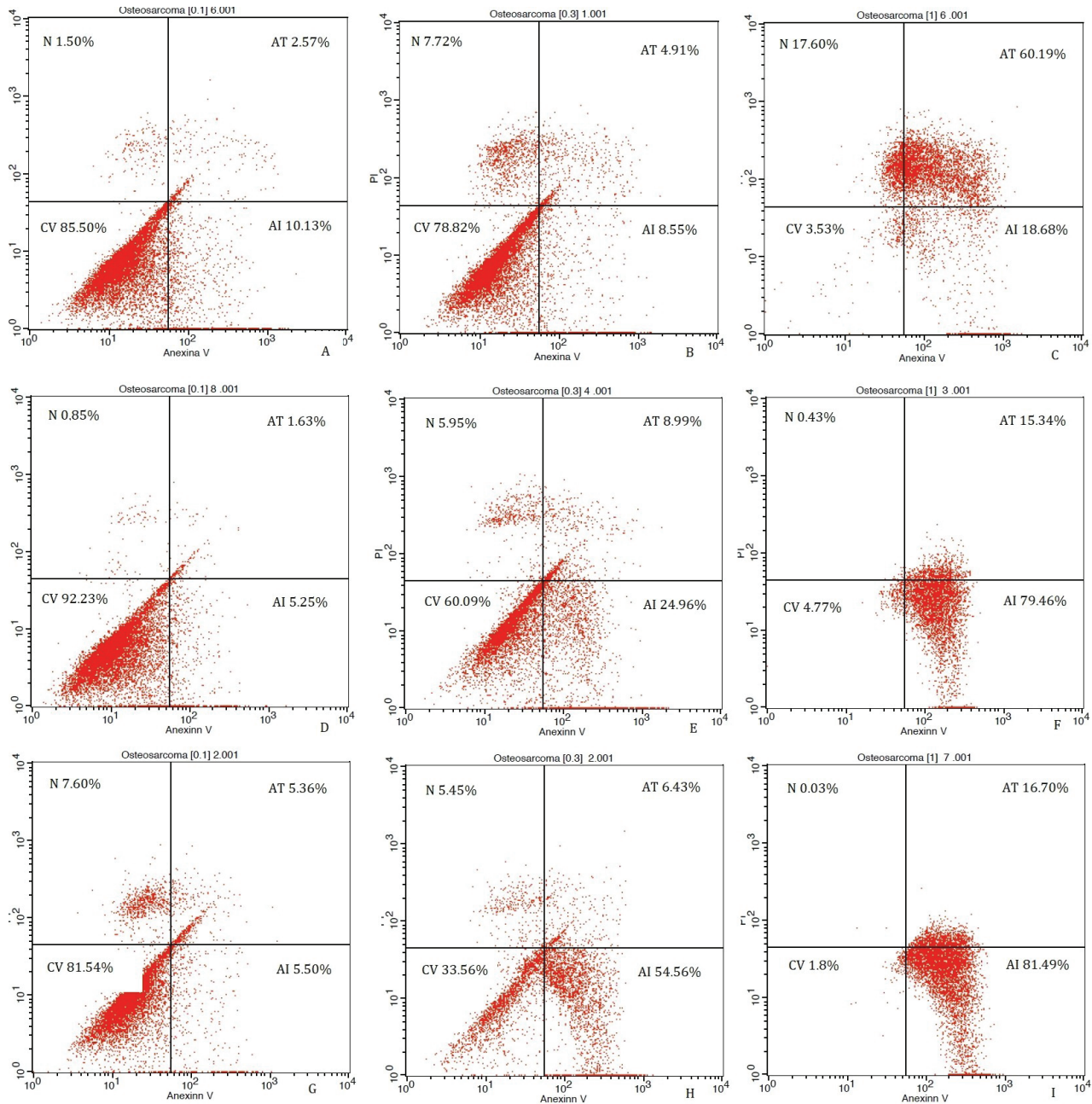

Fig.1. Representative images of samples from the analysis of the death of the cell mechanism promoted by $\beta$ Lapachone in the canine osteosarcoma cells, by means of the double marking test with Annexin V (X axis) and Propidium Iodine (Y axis). (A) $0.1 \mu \mathrm{m} / 24 \mathrm{~h}$. (B) $0.3 \mu \mathrm{m} / 24 \mathrm{~h}$. (C) $1.0 \mu \mathrm{m} / 24 \mathrm{~h}$. (D) $0.1 \mu \mathrm{m} / 48 \mathrm{~h}$. (E) $0.3 \mu \mathrm{m} / 48 \mathrm{~h}$. (F) $1.0 \mu \mathrm{m} / 48 \mathrm{~h}$. (G) $0.1 \mu \mathrm{m} / 72 \mathrm{~h}$. (H) $0.3 \mu \mathrm{m} / 72 \mathrm{~h}$. (I) $1.0 \mu \mathrm{m} / 72 \mathrm{~h}$. $\mathrm{N}=$ death of the cell by necrosis, $\mathrm{AT}=$ late apoptosis, $\mathrm{CV}=$ viable cells, $\mathrm{AI}=$ initial apoptosis. Flow Cytometer (Facscalibur, $\mathrm{BD}$ Biosciences).

The effect of $\beta$-lapachone on the mitochondrial membrane potential was measured for 24 hours, using the lipophilic dye JC-1 (Fig.2). Mitochondrial depolarization occurred in a dose-dependent manner. Data on mitochondrial membrane potential, promoted by $\beta$ Lapachone in canine osteosarcoma cells, are presented in Table 2. Apoptosis was lower in the concentration of $0.1 \mu \mathrm{m}(14.86 \%)$ and higher in the concentration of $1.0 \mu \mathrm{m}(88.13 \%)$.

The values indicated that apoptosis triggered by $\beta$ Lapachone may be related to the rupture of the integrity of the mitochondrial membrane potential. According to this result, Pardee et al. (2002) reported that $\beta$ Lapachone causes release of cytochrome $c$, a protein associated with the internal membrane of the mitochondria, which inhibits the cell cycle. Thus, $\beta$ Lapachone plays a selective antineoplastic action in mitochondrial mutations, frequent in tumor cells. Galluzzi et al. (2012) describe as intrinsic apoptosis the cell death that begins in the external mitochondrial membrane or may result from the transition of mitochondrial permeability.
Table 2. Average of the data provided by the flow cytometer on the mitochondrial membrane potential, using the lipophilic dye JC-1

\begin{tabular}{cccc}
\hline $\begin{array}{c}\text { Treatment time } \\
\text { (hours) }\end{array}$ & Concentration & $\begin{array}{c}\text { Viable } \\
\text { cells }\end{array}$ & Apoptosis \\
\hline 24 & $\mathrm{NC}^{*}$ & 95.15 & 3.47 \\
& $01 \mu \mathrm{M}$ & 83.45 & 16.22 \\
& $0.3 \mu \mathrm{M}$ & 54.91 & 38.80 \\
& $1.0 \mu \mathrm{M}$ & 12.77 & 83.45
\end{tabular}

Presentation of data on the potential of mitochondrial membrane, promoted by $\beta$ Lapachone in canine osteosarcoma cells. ${ }^{*} \mathrm{NC}=$ Negative control.

The values found were evaluated by the GraphPad Prism Statistical graphics program, using the bidirectional ANOVA method. There was no statistically significant difference between repetitions and triplicate values in each concentration $(p=0.9583)$. However, there was a statistically significant 

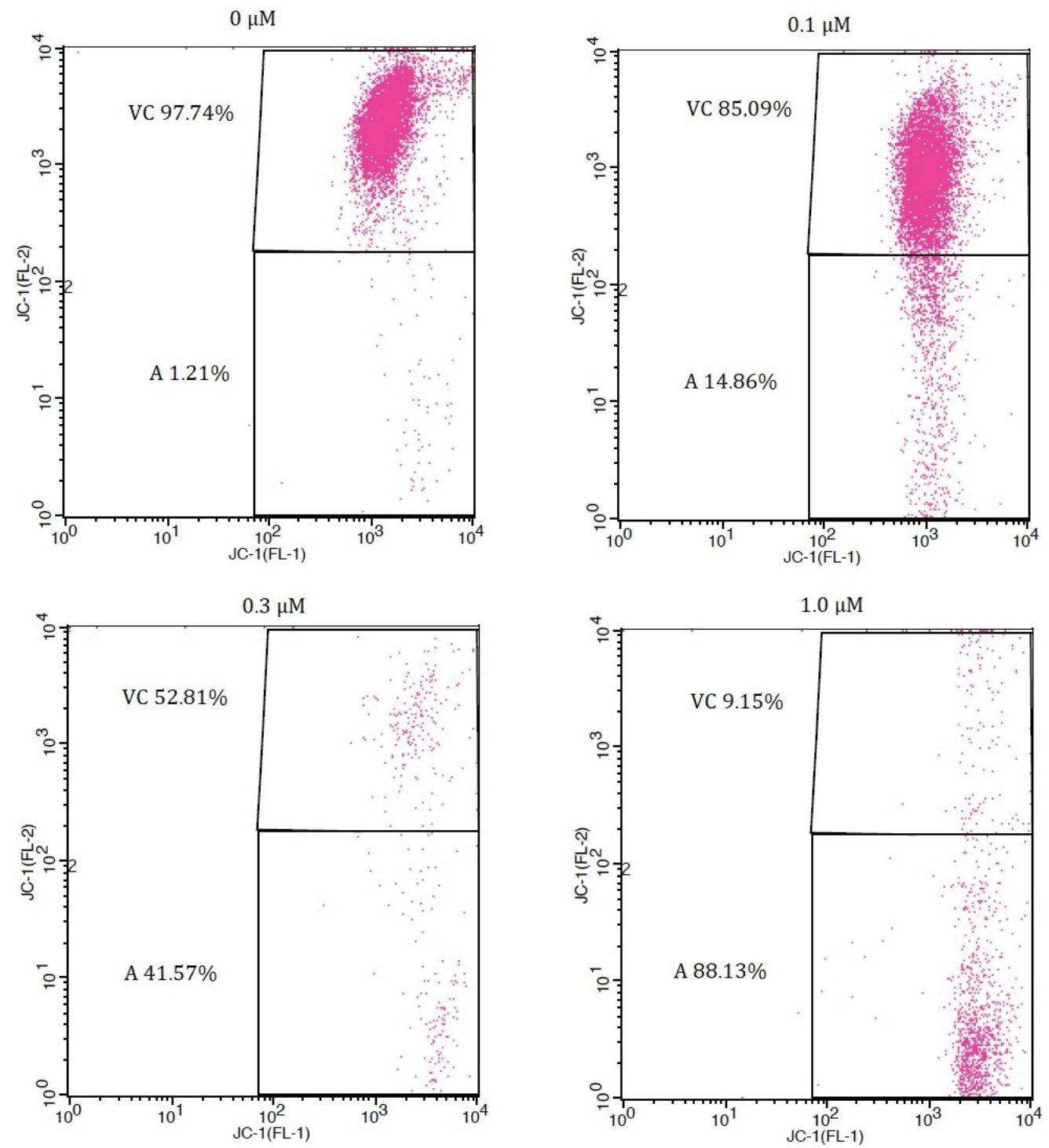

Fig.2. Analysis of the effect of different concentrations of $\beta$ Lapachone in 24 hours on the mitochondrial membrane potential in the canine osteosarcoma cells, by using the lipophilic dye JC-1. There was a marked increase in apoptosis (A) and decreased cell viability (VC) in the concentration of $1.0 \mu \mathrm{m}$. FL-1 = fluorescence channel 1 ; FL-2 = fluorescence channel 2. Flow Cytometer (Facscalibur, BD Biosciences).

difference between the results found in the concentrations used $(\mathrm{p}<0.0001)$. Mitochondrial depolarization was lower in the group treated with $0.1 \mu \mathrm{m}$ of $\beta$ Lapachone $(3.47 \%)$ and higher in the group treated with $1.0 \mu \mathrm{m}$ of $\beta$ Lapachone $(83.45 \%)$. The induction of the integrity loss of the mitochondrial membrane potential also occurred in cells of canine osteosarcoma treated for 3 hours, with $30 \mu \mathrm{g} / \mathrm{ml}$ of $\alpha$ mangostin, substance extracted from mangosteen, tropical fruit found in Southeast Asia (Krajarng et al. 2012).

The phases of the cell cycle were characterized by the percentage of cells of canine osteosarcoma, after treatment with $\beta$ lapachone, in sub-G1, G0/G1, S, and G2/M. Data on the analysis of cell cycle blockade, promoted by $\beta$ Lapachone in cells of osteosarcoma, are presented in Table 3 . There was a significant statistical difference $(\mathrm{p}<0.0001)$ between exposure times. In the $\mathrm{G}_{24}$ (Fig.3) there was similarity between the number of cells in the phase G0/G1 and S. With this exposure
Table 3. Mean of the data provided by the flow cytometer on the analysis of the cell cycle blockade of the D-17 lineage after treatment with $\beta$ Lapachone

\begin{tabular}{cccccr}
\hline \multirow{2}{*}{$\begin{array}{c}\text { Treatment time } \\
\text { (hours) }\end{array}$} & Concentration & \multicolumn{4}{c}{ Cell cycle phases } \\
\cline { 3 - 6 } & & SUB-G1 & G0/G1 & S & G2/M \\
\hline 24 & $0.1 \mu \mathrm{M}$ & 0.75 & 46.42 & 49.13 & 8.67 \\
& $0.3 \mu \mathrm{M}$ & 7.35 & 43.46 & 52.11 & 4.43 \\
& $1.0 \mu \mathrm{M}$ & 2.69 & 58.44 & 41.56 & 0.00 \\
48 & $0.1 \mu \mathrm{M}$ & 0.00 & 72.74 & 27.20 & 0.05 \\
& $0.3 \mu \mathrm{M}$ & 0.81 & 65.74 & 33.80 & 0.45 \\
& $1.0 \mu \mathrm{M}$ & 4.67 & 71.08 & 18.10 & 12.96 \\
72 & $0.1 \mu \mathrm{M}$ & 0.02 & 69.03 & 29.12 & 1.84 \\
& $0.3 \mu \mathrm{M}$ & 1.45 & 64.99 & 32.01 & 2.98 \\
& $1.0 \mu \mathrm{M}$ & 11.92 & 66.48 & 12.02 & 21.52
\end{tabular}

Presentation of data on the analysis of cell cycle blockade, promoted by $\beta$ Lapachone in canine osteosarcoma cells. 
time, the cells can synthesize the proteins needed so that each chromosome can replicate. However, this event depends on the origin and the cellular type (Pardee et al. 2002).

The difference between phases increased significantly in $G_{48}$ and $G_{72}$ (Fig.4), predominating in the phases $G 0 / G 1$, which corresponds to the interval between mitosis and DNA duplication. As the cycle progresses to the transition G0/G1, there is the stimulus to transcription of the genes involved in the progression of the cell cycle, which encode the proteins c-Myc, p53, pRb, Ras, PKA, PKC, Bcl-2, NF- $\kappa B, C D K$, cyclins and CKI. The blockade at the checkpoint, in the G1/S phase, generates mechanisms to prevent the formation of anomalous cells, perform the repair or induce apoptosis (Zörnig et al. 2001, Brooks \& Gu 2006, Wu et al. 2006, Maximov \& Maximov 2008). In addition, $\beta$ Lapachone has as its property the ability to inhibit the topoisomerases complex, not letting them

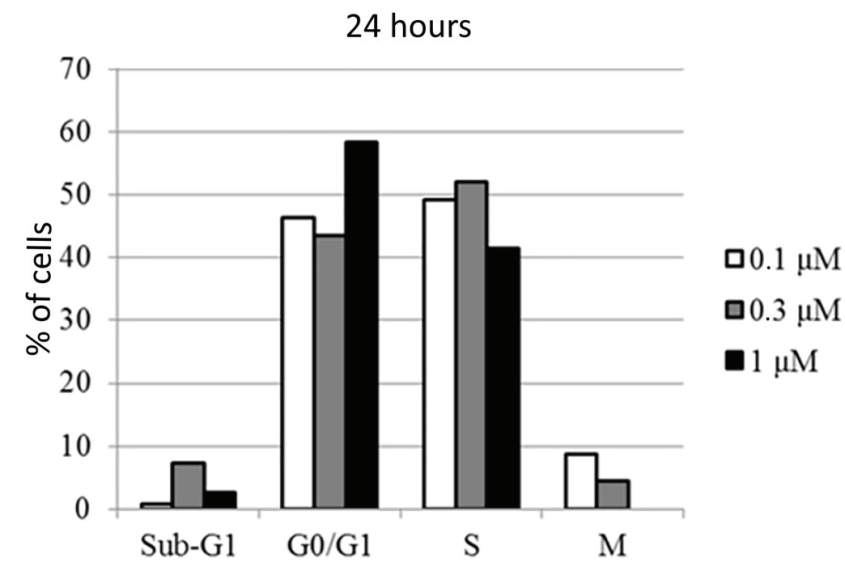

Fig.3. Graphical representation of the result of the cell cycle kinetics for $G_{24}$. It is noted the similarity between the number of cells in the $\mathrm{G0} / \mathrm{G} 1$ and $\mathrm{S}$ phases. $\mathrm{X}$ axis = phases of the cell cycle, Y-axis $=$ number of cells. GraphPad Prism ${ }^{\circledR}$ program. reconnect to the DNA and undoing the complex. Thus, the activation of checkpoints in the cell division process occurs, inducing the death of malignant cells (Silva et al. 2003).

There was no statistical difference between the concentrations used during the treatment of this experiment and the blockade of the cell cycle. A distinct result occurred in the HBL-100, HeLa, SW1573 and WiDr strains of human solid tumors, in which changes in the cell cycle were dependent on the concentration of $\beta$-lapachone (Rios-Luci et al. 2012). The present result also differs from that reported in HOS cells treated with baicalein, in which the distribution of cells in the G0/G1 phase increased in a dose-dependent manner (Zhang et al. 2013).

In this study, it was possible to realize that, at the dosage of $1.0 \mu \mathrm{m}$ in $\mathrm{G}_{48}$ and $\mathrm{G}_{72}$, there were cells locked in the $\mathrm{G} 2 / \mathrm{M}$ phase, inducing the mitotic catastrophe. For Pardee et al. (2002), chromosomal aberrations can be created indirectly by the long exposure of $\beta$ Lapachone to high concentrations, and these cells are blocked in the G2/M phase. Galluzzi et al. (2012) reported that cell cycle blockade, when there is an attempt to divide cells with damaged DNA, characterizes the mitotic catastrophe.

In summary, inhibition of the growth of canine osteosarcoma cells after treatment with $\beta$ Lapachone occurred by blocking the cycle in G0/G1 phase and significantly increased with exposure time. The same occurred with cells of canine osteosarcoma treated with $\alpha$-mangostin (Krajarng et al. 2012). This differs from the antineoplastic agents used in the routine for the treatment of osteosarcoma, such as cisplatin, carboplatin, doxorubicin and methotrexate. These agents inhibit the synthesis of DNA in the $S$ phase of the cell cycle (Almeida et al. 2005). Similarly, the human cells of colon cancer and hepatoma, treated by $\beta$ lapachone, are also inhibiting in the $S$ phase (Pardee et al. 2002).

This study seems to be the first to evaluate the antiproliferative effects of $\beta$ LP as a treatment for OSC cells in vitro, demonstrating that the compound effectively presented antiproliferative activity and cytotoxic effect on the tested cell type. The dosage
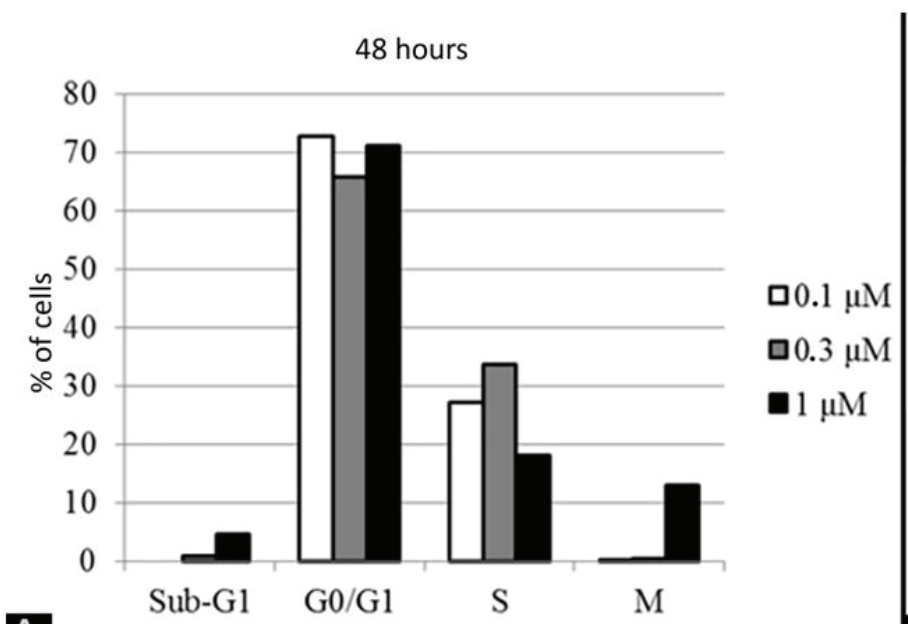

A

Fig.4. (A) Graphic representation of the result of the cell cycle kinetics for $G_{48}$ and (B) $G_{72}$. It is noted that the inhibition of growth occurred by the blockade of the cycle in the G0/G1 phase and increased with the exposure time. $\mathrm{X}$ axis = phases of the cell cycle, $\mathrm{Y}$ axis $=$ number of cells. GraphPad Prism ${ }^{\circledR}$ program. 
of $0.3 \mu \mathrm{m}$ showed to be the most promising, suggesting that, in low concentration, it is possible to obtain the desired therapeutic action, associated with the possibility of minor adverse effects. Initial apoptosis was the most frequent type of cell death in all groups, related to the rupture of the integrity of the mitochondrial membrane potential, indicating the occurrence of intrinsic apoptosis. Inhibition of cell growth occurred by blocking the cycle in phase G0/G1. Thus, it is possible that the formation of checkpoints in the cell division process has occurred, inducing the death of the cells of canine osteosarcoma in low concentration.

Although the results of this research are very promising, in vivo studies are necessary to allow the validation of the possible clinical use of $\beta$ LP in animals and humans. Strategies such as the observation of this treatment in xenografts of osteosarcoma cells in laboratory animals and subsequent therapeutic use in natural cases of the tumor will be important to determine the systemic and local action of the substance on neoplastic cells, as well as possible adverse effects provided.

\section{CONCLUSION}

$\beta$ Lapachone has cytotoxic effects on canine osteosarcoma cells, induces apoptosis and promotes cell cycle blockage in G0/G1phase.

\section{REFERENCES}

Aires A.L., Ximenes E.C.P.A., Silva R.A.R., Barbosa V.X., Góes A.J.S., Peixoto C.A., Souza V.M.O. \& Albuquerque M.C.P.A. 2014. Ultrastructural analysis of $\beta$-lapachone-induced surface membrane damage in male adult Schistosoma mansoni BH strain worms. Exp. Parasitol. 142:83-90. <http://dx.doi. org/10.1016/j.exppara.2014.04.010> <PMid:24768955>

Almeida V.L., Leitão A., Reina L.C.B., Montanari C.A., Donnici C.L. \& Lopes M.T.P. 2005. Câncer e agentes antineoplásicos ciclo-celular específicos e ciclo-celular não específicos que interagem com o DNA: uma introdução. Quím. Nova 28(1):118-129. <http://dx.doi.org/10.1590/S0100-40422005000100021>

Batschinski K., Dervisis N.G. \& Kitchell B.E. 2014. Evaluation of ifosfamide salvage therapy for metastatic canine osteosarcoma. Vet. Comp. Oncol. 12(4):249-257. <http://dx.doi.org/10.1111/j.1476-5829.2012.00355. $\mathrm{x}><$ PMid:22985083>

Brooks C.L. \& Gu W. 2006. p.53, ubiquitination: Mdm2 and beyond. Mol. Cell 21(3):307-315. <http://dx.doi.org/10.1016/j.molcel.2006.01.020> <PMid:16455486>

Cao L., Li L.S., Spruell C., Xiao L., Chakrabarti G., Bey E.A., Reinicke K.E., Srougi M.C., Moore Z., Dong Y., Vo P., Kabbani W., Yang C.R., Wang X., Fattah F., Morales J.C., Motea E.A., Bornmann W.G., Yordy J.S. \& Boothman D.A. 2014. Tumor-selective, futile redox cycle-induced bystander effects elicited by NQ01 bioactivatable radiosensitizing drugs in triple-negative breast cancers. Antioxid. Redox Signaling 21(2):237-250. <http://dx.doi. org/10.1089/ars.2013.5462><PMid:24512128>

Chang Z., Huo L., Li K., Wu Y. \& Hu Z. 2014. Blocked autophagy by miR-101 enhances osteosarcoma cell chemosensitivity in vitro. Scient. World J. 2014:794756. <PMid:25013866>

Cinegaglia N.C., Bersano P.R.O., Búfalo M.C. \& Sforcin J.M. 2013. Cytotoxic action of brazilian propolis in vitro on canine osteosarcoma cells. Phytother. Res. 27(9):1277-1281.<http://dx.doi.org/10.1002/ptr.4861><PMid:23074147>

Docampo R., Cruz F.S., Boveris A., Muniz R.P. \& Esquivel D.M. 1979. ß-Lapachone enhancement of lipid peroxidation and superoxide anion and hydrogen peroxide formation by sarcoma 180 ascites tumor cells. Biochem. Pharmacol. 28(6):723-728. <http://dx.doi.org/10.1016/0006-2952(79)90348-4> $<$ PMid:222291>
Flick H.E., Lalonde J.M., Malachowski W.P. \& Muller A.J. 2013. The tumorselective cytotoxic agent $\beta$-lapachone is a potent inhibitor of ID01. Int. J. Tryptophan Res. 6:35-45. <http://dx.doi.org/10.4137/IJTR.S12094> <PMid:24023520>

Fonseca S.G.C., Braga R.M.C. \& Santana D.P. 2003. Lapachol: química, farmacologia e métodos de dosagem. Revta Bras. Farm. 84(1):9-16.

Gallagher R., Keighley J., Tancabelic J., Garimella R., Pinson D., Templeton K. \& Tawfik O. 2012. Clinicopathologic correlation of vitamin D receptor expression with retinoid X receptor and MIB-1 expression in primary and metastatic osteosarcoma. Ann. Diagn. Pathol. 16(5):323-329. <http://dx.doi. org/10.1016/j.anndiagpath.2012.01.001> <PMid:22542077>

Galluzzi L., Vitale I., Abrams J.M., Alnemri E.S., Baehrecke E.H., Blagosklonny M.V., Dawson T.M., Dawson V.L., El-Deiry W.S., Fulda S., Gottlieb E., Green D.R., Hengartner M.O., Kepp O., Knight R.A., Kumar S., Lipton S.A., Lu X., Madeo F., Malorni W., Mehlen P., Nuñez G., Peter M.E., Piacentini M., Rubinsztein D.C., Shi Y., Simon H.U., Vandenabeele P., White E., Yuan J., Zhivotovsky B., Melino G. \& Kroemer G.. 2012. Molecular definitions of cell death subroutines: recommendations of the nomenclature committee on cell death. Cell Death Differ. 19:107-120.<http://dx.doi.org/10.1038/ cdd.2011.96> <PMid:21760595>

Hofstaetter J.G., Roschger A., Puchner S., Dominkus M., Sulzbacher I., Windhager R., Klaushofer K. \& Roschger P. 2013. Altered matrix mineralization in a case of a sclerosing osteosarcoma. Bone 53(2):409-413. <http://dx.doi org/10.1016/j.bone.2012.12.043><PMid:23291608>

Hussain H., Krohn K., Ahmad V.U., Miana G.A. \& Green I.R. 2007. Lapachol: an overview. Arkivoc (II):145-171.

Karnik K.S., Samii V.F., Weisbrode S.W., London C.A. \& Green E.M. 2012. Accuracy of computed tomography in determining lesion size in canine appendicular osteosarcoma. Vet. Radiol. Ultrasound 53(3):273-279. <PMid:22413965>

Klaus V., Hartmann T., Gambini J., Graf P., Stahl W., Hartwig A. \& Klotz L.O. 2010. 1,4-Naphthoquinones as inducers of oxidative damage and stress signaling in HaCaT human keratinocytes. Arch. Biochem. Biophys. 496(2):93100.<http://dx.doi.org/10.1016/j.abb.2010.02.002><PMid:20153715>

Krajarng A., Nilwarankoon S., Suksamrarn S. \& Watanapokasin R. 2012. Antiproliferative effect of a-mangostin on canine osteosarcoma cells. Res. Vet. Sci. 93(2):788-794. <http://dx.doi.org/10.1016/j.rvsc.2012.01.015> <PMid:22342127>

Kung H.N., Weng T.Y., Liu Y.L., Lu K.S. \& Chau Y.P. 2014. Sulindac compounds facilitate the cytotoxicity of $\beta$ lapachone by up-regulation of $\mathrm{NAD}(\mathrm{P}) \mathrm{H}$ quinone oxidoreductase in human lung cancer cells. Plos One 9(2):e88122. <http://dx.doi.org/10.1371/journal.pone.0088122><PMid:24505400>

Liu Z.F., Liang Z.Q., Li L., Zhou Y.B., Wang Z.B., Gu W.F., Tu L.Y. \& Zhao J. 2016. MiR-335 functions as a tumor suppressor and regulates survivin expression in osteosarcoma. Eur. Rev. Med. Pharmacol. Sci. 20(7):12511257. <PMid:27097943>

Lu Y.C., Chou C.T., Liang W.Z., Kuo C.C., Hsu S.S., Wang J.L. \& Jan C.R. 2017. Effect of methoxsalen on $\mathrm{Ca} 2+$ homeostasis and viability in human osteosarcoma cells. Chin. J. Physiol. 60(3):174-182. <http://dx.doi.org/10.4077/CJP.2017. BAF482><PMid:28629211>

Martín-Navarro C.M., López-Arencibia A., Lorenzo-Morales J., OramasRoyo S., Hernández-Molina R., Estévez-Braun A., Ravelo A.G., Valladares B. \& Piñero J.E. 2010. Acanthamoeba castellanii Neff: In vitro activity against the trophozoite stage of a natural sesquiterpene and a synthetic cobalt(II)-lapachol complex. Exp. Parasitol. 126(1):106-108. <http://dx.doi. org/10.1016/j.exppara.2009.12.015><PMid:20045692>

Maximov G. \& Maximov K. 2008. The role of p53 tumor-suppressor protein in apoptosis and cancerogenesis. Biotechnol. Biotechnological Equipment 22(2):664-668. <http://dx.doi.org/10.1080/13102818.2008.10817532>

Mosmann T. 1983. Rapid colorimetric assay for cellular growth and survival: application to proliferation and cytotoxicity assays. J. Immunol. Methods 65(1/2):55-63. <http://dx.doi.org/10.1016/0022-1759(83)90303-4> <PMid:6606682> 
Nelson R.W. \& Couto C.G. 2015. Medicina Interna de Pequenos Animais. 5a ed. Elsevier, Rio de Janeiro, p.1512.

Neuwald E.B., Velga D.C., Oliveira E.C. \& Contesini E.A. 2006. Osteossarcoma craniano em um cão. Acta Scient. Vet. 34:215-219.

Osborne T.S. \& Khanna C. 2012. A Review of the association between osteosarcoma metastasis and protein translation. J. Comp. Pathol. 146(2/3):132-142. <http://dx.doi.org/10.1016/j.jcpa.2011.12.007> <PMid:22297074>

Ouyang L., Liu P., Yang S., Ye S., Xu W. \& Liu X. 2013. A three-plasma miRNA signature serves as novel biomarkers for osteosarcoma. Med. Oncol. 30(1):340. <https://doi.org/10.1007/s12032-012-0340-7><PMid:23269581>

Pardee A.B., Li Y.Z. \& Li C.J. 2002. Cancer Therapy with ß-Lapachone. Curr. Cancer Drug Targets 2(3):227-242.<http://dx.doi.org/10.2174/1568009023333854> $<$ PMid:12188909>

Park E.J., Min K.J., Lee T.J., Yoo Y.H., Kim Y.S. \& Kwon T.K. 2014. b-Lapachone induces programmed necrosis through the RIP1-PARP-AIF-dependent pathway in human hepatocellular carcinoma SK-Hep1 cells. Cell Death Dis. 5:e1230.

Peres C.M. \& Curi R. 2005. Como Cultivar Células. Guanabara Koogan, Rio de Janeiro, p.304.

Plumb J.A. 2004. Cell Sensitivity Assays: Clonogenic Assay, p.165-179. In: Langdon S.P. (Ed.), Cancer Cell Culture Methods and Protocols. Humana Press Incorp., Totowa.

Regan R.C., Gogal Jr R.M., Barber J.P., Tuckfield R.C., Howerth E.W. \& Lawrence J.A. 2014. Cytotoxic effects of loperamide hydrochloride on canine cancer cells. J. Vet. Med. Sci. 76(12):1563-1568. <http://dx.doi.org/10.1292/ jvms.13-0537><PMid:25649936>

Ríos-Luci C., Bonifazi E., León L.G., Montero J.C., Burton G., Pandiella A., Misico R.I. \& Padrón J.M. 2012. $\beta$-Lapachone analogs with enhanced antiproliferative activity. Eur. J. Med. Chem. 53:264-274. <http://dx.doi. org/10.1016/j.ejmech.2012.04.008><PMid:22560628>

Robson H., Meyer S., Shalet S.M., Anderson E., Roberts S. \& Eden O.B. 2007. Platinum agents in the treatment of osteosarcoma: efficacy of cisplatin Vs carboplatin in human osteosarcoma cell lines. Med. Pediatric Oncol. 39(6):573-580.<http://dx.doi.org/10.1002/mpo.10076><PMid:12376980>

Shoeneman J.K., Ehrhart 3rd E.J., Eickhoff J.C., Charles J.B., Powers B.E. \& Thamm D.H. 2012. Expression and function of survivin in canine osteosarcoma. Cancer Res. 72(1):249-259. <http://dx.doi.org/10.1158/0008-5472. CAN-11-2315><PMid:22068035>
Silva A.R. 2009. Obtenção de derivados do lapachol e de compostos relacionados. Tese de Doutorado, Programa de Pós-Graduação em Química, Instituto de Ciências Exatas, Universidade Federal Rural do Rio de Janeiro, Seropédica, RJ. 300p.

Silva M.N., Ferreira V.F. \& Souza M.C.B.V. 2003. Um panorama atual da química e da farmacologia de naftoquinonas, com ênfase na b-lapachona e derivados. Quím. Nova 26(3):407-416. <http://dx.doi.org/10.1590/ S0100-40422003000300019>

Silva R.S.F., Leitão G.G., Brum T.B., Lobato A.P.G., Pinto M.C.F.R. \& Pinto A.V. 2007. Applications of counter-current chromatography in organic synthesis purification of heterocyclic derivatives of lapachol. J. Chromatogr. A 1151(1/2):197-202.<http://dx.doi.org/10.1016/j.chroma.2007.03.066> <PMid:17408681>

Souza C.D. \& Felfili J.M. 2006. Uso de plantas medicinais na região de Alto Paraíso de Goiás, GO, Brasil. Acta Bot. Bras. 20(1):135-142.<http://dx.doi. org/10.1590/S0102-33062006000100013>

Stein T.J., Holmes K.E., Muthuswamy A., Thompson V. \& Huelsmeyer M.K. 2011. Characterization of $\beta$-catenin expression in canine osteosarcoma. Vet. Comp. Oncol. 9(1):65-73.<http://dx.doi.org/10.1111/j.1476-5829.2010.00236. $\mathrm{x}><$ PMid:21303455>

Thomson R.H. 1997. Naturally Ocurring Quinones IV Recent Advances. 4th ed. Chapman and Hall, London, p.280.

Wu H., Hayashi T. \& Inoue M. 2006. Immunohistochemical expression of Mdm2 and p53 in canine cutaneous mast cell tumours. J. Vet. Med. A 53(2):65-68. <http://dx.doi.org/10.1111/j.1439-0442.2006.00795.x> $<$ PMid:16466457>

Yu H.Y., Kim S.O.K., Jin C.Y., Kim G.Y., Kim W.J., Yoo Y.H. \& Choi Y.H. 2014. b-lapachone-induced apoptosis of human gastric carcinoma AGS cells is caspase-dependent and regulated by the PI3K/Akt pathway. Biomol. Ther. 22(3):184-192. <http://dx.doi.org/10.4062/biomolther.2014.026> <PMid:25009698>

Zhang Y., Song L., Cai L., Wei R., Hu H. \& Jin W. 2013. Effects of baicalein on apoptosis, cell cycle arrest, migration and invasion of osteosarcoma cells. Food Chem. Toxicol. 53:325-333. <http://dx.doi.org/10.1016/j. fct.2012.12.019><PMid:23266503>

Zörnig M., Hueber A., Baum W. \& Evan G. 2001. Apoptosis regulators and their role in tumorigenesis. [. Biochim. Biophys. Acta 1551(2):1-37. <PMid:11591448> 